\title{
MICROBIAL FLORA OF SMOKE-DRIED CATFISH (CLARIAS GARIEPINUS) PROCESSED AND SOLD IN SOME ABATTOIRS IN BAYELSA AND RIVERS STATES
}

\author{
Ariyo Adenike Bosede* and Obire Omokaro \\ Department of Microbiology, Federal University, Otuoke, Bayelsa State and ${ }^{2}$ Department of \\ Microbiology, Rivers State University, Nkpolu-Oroworukwo, Port Harcourt, Nigeria \\ *Corresponding Author E-mail: adenikeariyo155@gmail.com
}

Cite this article:

Ariyo A.B., Omokaro O. (2021), Microbial Flora of Smoke-Dried Catfish (Clarias Gariepinus) Processed and Sold in Some Abattoirs in Bayelsa and Rivers States. African Journal of Environment and Natural Science Research 4(4), 123 133. DOI: $10.52589 / A J E N S R-$ ABXTE95X.

\section{Manuscript History \\ Received: 19 Oct 2021 \\ Accepted: 9 Nov 2021 \\ Published: 27 Nov 2021}

Copyright $\odot 2020$ The Author(s). This is an Open Access article distributed under the terms of Creative Commons AttributionNonCommercial-NoDerivatives 4.0 International (CC BY-NC-ND 4.0 ), which permits anyone to share, use, reproduce and redistribute in any medium, provided the original author and source are credited.
ABSTRACT: The microflora of smoked catfish (Clarias gariepinus) sold in some abattoirs in Bayelsa and Rivers States were investigated. Smoked catfish samples were purchased within abattoirs and aseptically transported in ice-packed coolers to the laboratory. The total heterotrophic bacteria, total coliform, total hydrocarbon utilizing bacteria, total fungi and hydrocarbon utilizing fungal counts and identification of isolates from samples were analyzed using standard microbiological methods. Mean values of counts obtained showed that total heterotrophic bacteria ranged from $5.4 \times 10^{6} \mathrm{CFU} / \mathrm{g}$ to $4.0 \times$ $10^{5} \mathrm{CFU} / \mathrm{g}$, total hydrocarbon utilizing bacteria ranged from $1.5 \times 10^{4}$ to $1.0 \times 10^{3} \mathrm{CFU} / \mathrm{g}$, total coliform ranged from $1.7 \times 10^{6} \mathrm{CFU} / \mathrm{g}$ to 0 , total fungi ranged from $4.3 \times 10^{4} \mathrm{CFU} / \mathrm{g}$ to $1.2 \times 10^{4} \mathrm{CFU} / \mathrm{g}$ and total hydrocarbon utilizing fungi ranged from $3.5 \times 10^{3} \mathrm{CFU} / \mathrm{g}$ to $1.1 \times$ $10^{3} \mathrm{CFU} / \mathrm{g}$. Kruskal Walis $\mathrm{H}$ test showed no significant differences $(\mathrm{P} \leq 0.05)$ in the total heterotrophic bacterial load nor in the total fungal load in the locations. Bacteria identified are Bacillus sp, Enterobacter sp, Escherichia coli, Micrococcus sp, Pseudomonas sp, Salmonella sp., and Shigella species. Bacillus sp, Pseudomonas sp and Micrococcus sp., were isolated in all the samples. Salmonella sp and Shigella sp occurred in Igbogene and Swale samples. Bacillus sp recorded the highest occurrence (34\%) while Enterobacter sp. and Micrococcus sp recorded the least $(7 \%)$. Bacteria with hydrocarbon utilizing potentials with percentage occurrence were Bacillus sp (70\%) and Pseudomonas sp (30\%). Fungi isolated were Aspergillus niger, A. flavus, Aspergillus fumigatus, Penicillium sp, Fusarium sp., and Rhizopus sp. Aspergillus species recorded the highest frequency (36.0\%) while Rhizopus sp recorded the least (9.83\%). Aspergillus niger, Fusarium sp and Penicillium sp were isolated from all the samples. Penicillium $\mathrm{sp}$ recorded hydrocarbon utilizing the potential and the highest percentage of occurrence $(35.89 \%)$. The presence of a high microbial load of pathogenic bacteria and known mycotoxin producing fungi in the smoke-dried catfish are of great public health significance.

KEYWORDS: Smoked Catfish, Abattoir, Clarias Gariepinus, Heterotrophic Bacteria, Heterotrophic Fungi, Hydrocarbon Utilizing Potential 


\section{INTRODUCTION}

Fish is a major source of protein and its harvesting, handling, processing and distribution provide livelihood for millions of people as well as foreign exchange earnings for many countries (Al- Jufaili and Opara, 2006). In the tropics, fish is regarded as one of the most important protein-rich food (Eyo, 2001). Fish consumption accounts for about 35 per cent of animal protein consumption in Nigeria. In turn, fish farming is a vibrant and dynamic commercial sector in Nigeria, ripe with investment and employment opportunities. The Catfish Farmers Association of Nigeria declared that Nigeria's catfish production has increased from 83,000 tonnes in 2006 to 900,000 tonnes in the year 2013 (Nigerian Pilot, 2015). In Nigeria, the catfish (Clarias gariepinus) is said to be a particularly significant freshwater fish and because of its distinct taste, flavour, and texture, it has been well accepted in most regions of the country. It's readily available and widely cultivated in ponds (Olayemi et al., 2012). Due to the rich nutritional value including the high moisture content of fishes, they are prone to microbial attack or spoilage. According to Daramola et al. (2020), microbial deterioration makes fish products one of the most perishable commodities on the planet, and around onethird of the world's food supply is lost each year as a result of microbial spoilage. Aberoumand, (2010) referred to fishes as perishable products that must be preserved as soon as possible since they deteriorate quickly after harvest at high ambient temperatures. Dead fishes deteriorate quickly especially when preservation or processing measures are not quickly enhanced to extend the shelf life (Okonta and Ekelemu, 2005). The deterioration of dead fish is a result of a myriad of physiological and microbial activities that takes place in the fish. Akinola et al. (2006) described many ways for preserving fish, including drying, smoking, freezing, chilling, and brining. However, smoke drying is the most common method of fish preservation in the Niger Delta. This might be due to the fact that most fishing communities do not have access to power to chill their catch. He stated that the conventional method's primitive nature, as well as a lack of control over the drying pace, can lead to under-or over-drying, exposing the fish to breakages, unexpected gusts, contamination from dust, filth, flies, and bug infestation. These traditional methods are still widely used in the Niger Delta region's major fishing villages. In other to decrease post-harvest losses, make healthy fish available to customers, and enhance the quality of fish and fisheries products, traditional techniques of preserving fish by fishermen must be improved in Nigeria as a whole. The traditional method of smoking fish in Nigeria may take up to 2 or 3 days of continuous heat and smoke action. This method of smoking results in the deposition of varying levels of smoke deposits on the smoked fish. Factors affecting the quantities of woodsmoke compounds deposited on the fish include the duration of smoke exposure, the type of wood used and the skill of the fish processor (Garcia and Simal, 2005). Since the practice of preserving fish by smoking in some parts of Nigeria is usually embarked by stark illiterates or barely literate people who have little or no knowledge of good manufacturing practices (Davis and Davis, 2009), the fishes could be poorly and unhygienically handled or processed. This study is, therefore, aimed at investigating the microbial burden of smoked catfishes sold in some abattoirs in Bayelsa and Rivers State. 


\section{MATERIALS AND METHODS}

\section{Sampling Location}

Smoke-dried catfish (Clarias gariepinus) samples (500g) were randomly sampled and purchased from people carrying out fish smoke-drying and selling activities within the abattoirs. Smoked catfish samples were purchased and collected from four abattoirs in Yenagoa Local Government Area of Bayelsa State and an abattoir in Obio-Akpor Local Government Area of Rivers State. The samples on the collection were aseptically transported in ice-packed coolers to the microbiology laboratory of the Rivers State University and were analyzed immediately.

Table 1: Map coordinates of the abattoir locations

\begin{tabular}{lll}
\hline Location & Northing $(\mathrm{N})$ & Easting (E) \\
\hline Igbogene & $5^{0} 2^{\prime} 17.8188^{\prime \prime}$ & $6^{0} 24^{\prime} 14.958^{\prime \prime}$ \\
Tombia & $4^{0} 57^{\prime} 17.8092^{\prime}$ & $6^{0} 20^{\prime} 53.2428^{\prime \prime}$ \\
Opolo & $4^{0} 56^{\prime} 52.764^{\prime \prime}$ & $6^{0} 20^{\prime} 3.984^{\prime}$ \\
Swale & $4^{0} 53^{\prime} 42.9576^{\prime \prime}$ & $6^{0} 16^{\prime} 39.7164 ”$ \\
Rumuokoro & $4^{0} 52^{\prime} 11.64^{\prime}$ & $7^{0} 01^{\prime} 026^{\prime \prime}$ \\
\hline
\end{tabular}

\section{Sample Preparation}

Samples were homogenized by blending to smoothness in alcohol sterilized Marlex blender and packaged into sterile medium-sized plastic bowl containers for analyses (Adesemoye $e t$ al., 2006).

\section{Isolation, Enumeration and Characterization of Microorganisms}

\section{Total Heterotrophic Bacteria (THB)}

This was determined with the nutrient agar using the pour plate technique as described by Prescott et al. (2005). Ten grams (10g) of blended catfish was weighed into a $250 \mathrm{ml}$ conical flask containing $90 \mathrm{ml}$ sterile normal saline to give an initial $10^{-1}$ dilution. One $\mathrm{ml}$ was taken from this dilution into the test tube containing $9 \mathrm{ml}$ of sterile normal saline to achieve $10^{-2}$ dilution. This sequence was repeated until dilution $10^{-6}$ was obtained. $1 \mathrm{ml}$ aliquot of the appropriate dilution was transferred aseptically unto sterile Petri dishes and $10 \mathrm{ml}$ of molten sterile agar cooled to about $45^{\circ} \mathrm{C}$ was added aseptically, swirled and allowed to solidify respectively. Samples were plated in duplicates. Plates were incubated in an inverted position at $35 \pm 2{ }^{\circ} \mathrm{C}$ for 24 hours after which viable colonies were counted.

\section{Total Coliform (TC)}

This was determined with MacConkey Agar using the spread plate technique as described by Prescott et al. (2005). Ten grams (10g) of blended catfish was weighed into a $250 \mathrm{ml}$ conical flask containing $90 \mathrm{ml}$ sterile normal saline to give an initial $10^{-1}$ dilution. One $\mathrm{ml}$ was taken from this dilution into the test tube containing $9 \mathrm{ml}$ of sterile normal saline to achieve $10^{-2}$ 
dilution. This sequence was repeated until dilution $10^{-6}$ was obtained. An aliquot $(0.1 \mathrm{ml})$ of the appropriate dilution was transferred aseptically onto the surface of pre-dried sterile Petri dishes. Plates were spread using a sterile bent glass rod and were incubated in an inverted position at $35 \pm 2{ }^{\circ} \mathrm{C}$ for 24 hours, after which, viable colonies were counted.

\section{Total Hydrocarbon Utilizing Bacteria (THUB)}

The Vapour Phase Transfer method of Mills and Colwell (1978) was adopted to determine the population of hydrocarbon utilizing bacteria. Aliquots $(0.1 \mathrm{ml})$ of the serially diluted samples were inoculated on mineral salt agar media using the spread plate technique as described by Odokuma (2003). Sterile filter paper discs soaked in filter-sterilized crude oil which served as the only carbon source in the mineral salt agar was placed aseptically to the cover of the inoculated agar plates. The plates were incubated for 5 days at $35 \pm 2{ }^{\circ} \mathrm{C}$ after which viable colonies were counted. After the incubation period, the mean of the colonies was recorded.

\section{Total Fungi Count (TF)}

This was determined using the Potato Dextrose Agar (PDA) onto which $1 \%$ of lactic acid was added to suppress bacterial growth (Okerentugba and Ezereonye, 2003). The spread plate technique as described by Prescott et al., (2005) was adopted. An aliquot $(0.1 \mathrm{ml})$ of the appropriate serially diluted samples were inoculated in duplicates onto sterile pre-dried PDA plates and then spread evenly with a sterile glass spreader. The plates were incubated at $25^{\circ} \mathrm{C}$ for about 5 days (Douglas and Robinson, 2018), after which, the colonies were counted and the mean of the count was recorded accordingly.

\section{Total Hydrocarbon Utilizing Fungi (THUF)}

The Vapour Phase Transfer method of Mills and Colwell (1978) was adopted to determine the population of hydrocarbon utilizing fungi. Aliquots $(0.1 \mathrm{ml})$ of the serially diluted samples were inoculated on mineral salt agar media added with $1 \%$ lactic acid to suppress bacterial growth (Okerentugba and Ezereonye, 2003), using the spread plate technique as described by Odokuma (2003). Sterile filter paper discs soaked in filter-sterilized crude oil which served as the only carbon source in the mineral salt agar was placed aseptically to the cover of the inoculated agar plates. The plates were incubated at $25^{\circ} \mathrm{C}$ (Douglas and Robinson, 2018) for about 5 days. After the incubation period, the mean of the colonies was recorded.

\section{Purification of Isolates}

After the incubation periods, morphologically distinct and discreet colonies were streaked on respective agar plates to obtain pure cultures. Pure isolates of total heterotrophic bacteria and total hydrocarbon utilizing bacteria were obtained by picking (with sterile wire loop) distinct culturally and morphologically different colonies from the various media plates and streaked on pre-dried NA plates while pure cultures of fungal isolates were streaked on pre-dried PDA plates. Plates for bacteria were incubated at $35 \pm 2{ }^{\circ} \mathrm{C}$ for 24 hours while the fungal plates were incubated at $25^{\circ} \mathrm{C}$ for about 5 days.

\section{Identification of Bacterial Isolates}

Pure bacteria isolates were identified by the method described by Collins et al., (1989) and Cheesebrough (2004). Pure bacterial isolates were subjected to Biochemical tests which 
include oxidase test, catalase test, indole test, methyl red test, Voges Proskauer test, starch hydrolysis test, urease test, citrate test, sugar fermentation test and Triple Sugar Iron agar test. The procedure for the respective biochemical tests was carried out according to standards (Cheesbrough, 2004). Bacterial isolates were identified with reference to the Bergey's Manual of Determinative Bacteriology (Holt et al, 1994).

\section{Identification of Fungal Isolates}

Pure mould isolates were identified using their morphological features followed by microscopic examination of their wet mounts prepared with lactophenol-cotton blue and reference made to a fungal identification atlas by Barnett and Hunter (1998). Yeast isolates were also identified using their morphological characteristics, followed by microscopic examination of their wet mount prepared with normal saline, reference was also made to a fungal identification atlas by Barnett and Hunter (1998). The yeast isolates were further identified using Gram-staining, Sugar fermentation, oxidation and fermentation tests.

\section{Statistical Analysis}

The mean and standard deviations of the microbial counts were computed. The Analysis of variance (ANOVA) was used in checking for significant differences while the Kruskal Walis $\mathrm{H}$ test was used in separating the mean. All analysis was done using SPSS (version 27).

\section{RESULTS}

\section{Result of Microbial Counts of Smoke-dried Catfish Samples}

The result of the mean values of microbial counts $\left(\log _{10} \mathrm{CFU} / \mathrm{g}\right.$ of catfish sample) of total heterotrophic bacteria, total coliform, total hydrocarbon utilizing bacterial, heterotrophic fungal and hydrocarbon utilizing fungal counts obtained from smoke-dried catfish samples are presented in Figure 1. The highest and lowest mean total heterotrophic bacterial counts of 5.4 $\times 10^{6} \mathrm{CFU} / \mathrm{g}$ and $4.0 \times 10^{5} \mathrm{CFU} / \mathrm{g}$ was obtained in smoked catfish samples from Igbogene and Tombia abattoir samples respectively. The statistical analysis showed that there was no significant difference $(\mathrm{P} \leq 0.05)$ in the total heterotrophic bacterial load obtained in roasted fish in all the locations. Results of coliform count ranged from $3.0 \times 10^{5}$ to $1.7 \times 10^{6}$. The highest and lowest coliform count was recorded in catfish samples from Igbogene and Opolo abattoirs, respectively. However, there were no Vibrio counts in all the smoked catfish examined in Tombia and Swale abattoirs. The highest and lowest mean total hydrocarbon utilizing bacterial count of $1.5 \times 10^{4}$ and $1.0 \times 10^{3}$ was obtained in smoked catfish samples from Igbogene and Swale abattoir samples respectively. The total heterotrophic fungal counts obtained in catfish ranged from $1.2 \times 10^{4}$ to $4.3 \times 10^{4} \mathrm{CFU} / \mathrm{g}$. The result showed that catfish samples from Igbogene had the highest heterotrophic fungal counts of $4.3 \times 10^{4}$ while catfish samples from Swale had the least total heterotrophic count of $1.2 \times 10^{4} \mathrm{CFU} / \mathrm{g}$. Total Hydrocarbon utilizing fungal counts was highest in Opolo abattoir samples at a record fungi load count of $3.5 \times$ $10^{3} \mathrm{CFU} / \mathrm{g}$ while the lowest was from samples obtained in Tombia abattoir at $1.1 \times 10^{3} \mathrm{CFU} / \mathrm{g}$ count. Statistical analysis using the A Kruskal-Wallis $\mathrm{H}$ test showed that there was no significant difference $(\mathrm{P} \leq 0.05)$ in the Total fungal and hydrocarbon utilizing fungal counts obtained in all the locations. 


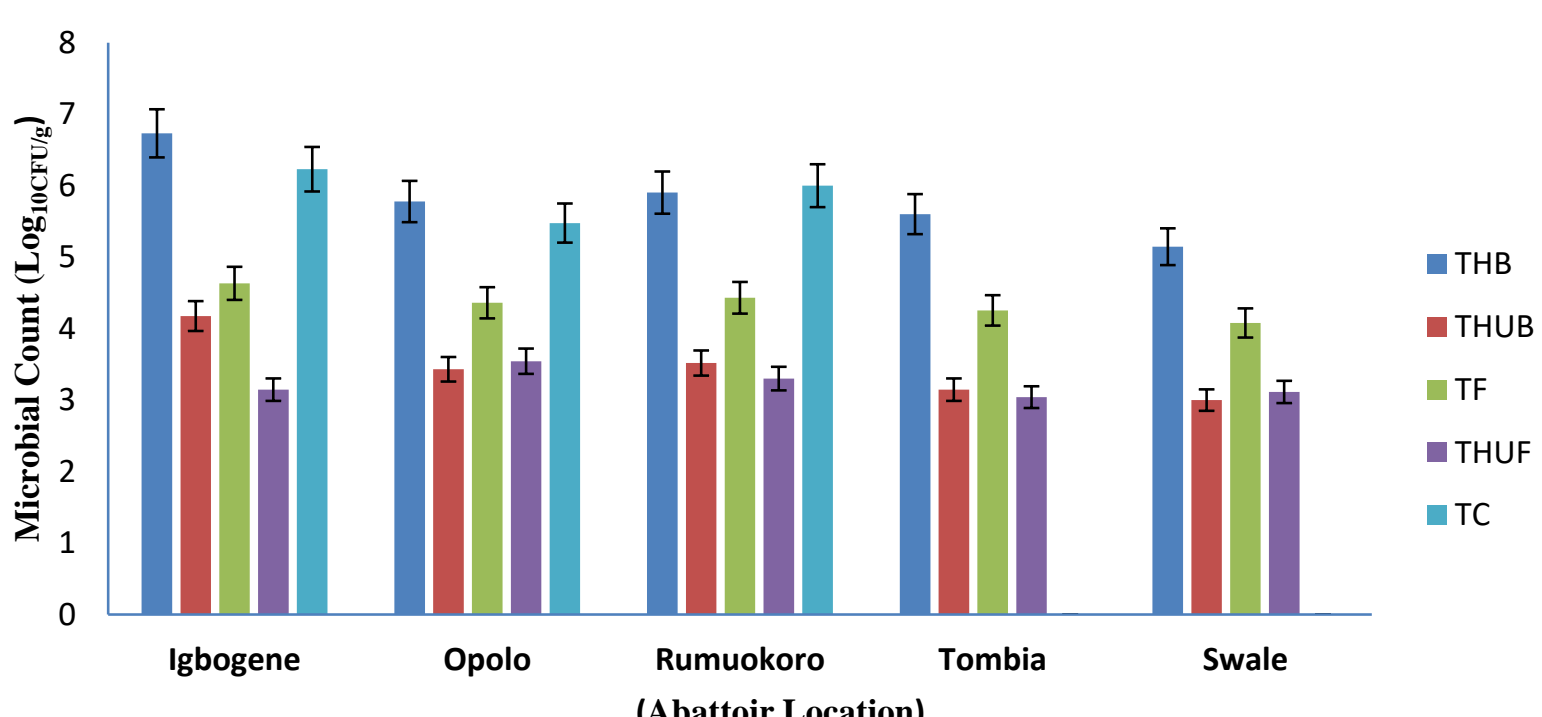

Fig 1: Microbial load of smoke-dried catfish samples sold in the vicinity of the Abattoirs

Key: THB $=$ Total heterotrophic bacteria; THUB $=$ total hydrocarbon utilizing bacteria; $\mathrm{TF}=$ total fungi; THUF = total hydrocarbon utilizing fungi; $\mathrm{TC}=$ total coliform

\section{Frequency of bacterial isolates in smoked catfish samples}

The distribution of characterized bacterial isolates in smoked catfish from the assessed abattoirs is presented in Figure 2. Bacterial isolates identified were Bacillus sp, Enterobacter sp, Escherichia coli, Micrococcus sp, Pseudomonas sp, Salmonella sp and Shigella sp were all isolated from catfishes in Igbogene abattoir, while Bacillus sp, Enterobacter sp, Escherichia coli, Micrococcus sp, and Pseudomonas sp were isolated from catfishes in Opolo abattoir. In catfishes bought from Rumuokoro, Bacillus sp, Escherichia coli, Micrococcus sp, and Pseudomonas sp were identified. In catfishes bought from Tombia, Bacillus sp, Micrococcus sp, and Pseudomonas sp were identified while in samples bought from Swale only had the presence of Bacillus sp, Micrococcus sp, Salmonella sp and Shigella sp. Also, E. coli was isolated in all catfish samples except those bought from Tombia and Swale abattoir and this agreed with the coliform counts which should not count in fishes from these regions. The Escherichia coli occurred in the order; Igbogene $>$ Rumuokoro $>$ Opolo. The percentages of occurrence of the organisms are Bacillus sp (34\%), Enterobacter sp (7\%), Escherichia coli (13\%), Micrococcus sp (7\%), Pseudomonas sp (13\%), Salmonella sp (13\%) and Shigella sp (13\%.). the percentage occurrence also showed that Bacillus sp were the most predominant bacterial isolates while Enterobacter sp and Micrococcus sp had the least percentages, The percentage occurrence of the bacteria with hydrocarbon utilizing potentials isolated from catfish is Bacillus sp (70\%) and Pseudomonas sp (30\%). The distribution of the bacterial isolates, as well as the hydrocarbon utilizing bacterial isolates, was not uniform and this could be due to certain factors including handling, processing, type of wood and the environment. 


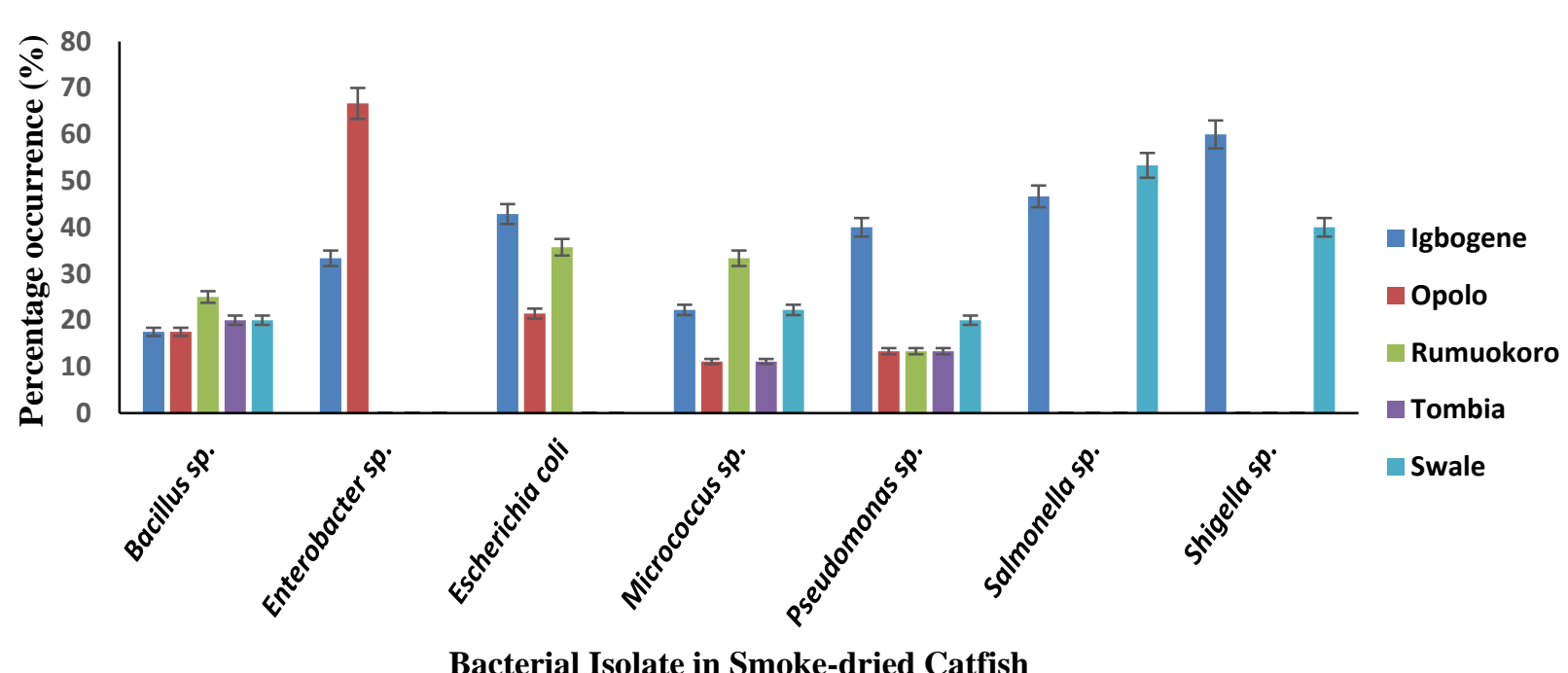

Fig. 2: Frequency of occurrence of bacteria isolated from smoke-dried catfish

\section{Frequency of occurrence of Fungi Isolates of smoke-dried catfish}

The distribution and population of fungi isolates found in catfish samples obtained from the abattoirs are enumerated in Figure 3. Fungi species identified from catfishes include Aspergillus niger, A. flavus, A. fumigatus, Penicillium sp, Fusarium sp. and Rhizopus sp in decreasing order. A. niger was isolated from catfish samples from Igbogene, Opolo, Rumuokoro, Tombia and Swale abattoirs. The highest number of isolations of Aspergillus niger was in samples collected from Tombia abattoir (26\%). Aspergillus flavus was obtained in samples collected from Opolo, Tombia and Swale abattoirs. Penicillium sp was present in all the samples and the highest number of isolates was in samples from Tombia (27.7\%) and Swale $(27.7 \%)$ abattoirs while the number of isolates was lowest in samples from Rumuokoro abattoir (11.1\%). Fusarium sp occurred in all the samples too and the highest count was in the Igbogene sample (33.3\%) while the lowest count was in the Rumuokoro samples $(6.6 \%)$. Rhizopus sp was absent in samples from Swale abattoir while it recorded a higher count in Opolo (33.3\%) and Tombia (33.3\%) with the lower count in Igbogene (20\%) and Rumuokoro (20\%) abattoirs. Aspergillus sp was the most frequently isolated with a percentage occurrence of $36.0 \%$ while Penicillium sp, Fusarium sp and Rhizopus sp were (29.59\%), (24.59\%) and $(9.83 \%)$, respectively. The percentages of occurrence of fungi with hydrocarbon utilizing potentials in catfish are Penicillium sp (35.89\%), Aspergillus sp (28.20\%), Rhizopus sp (20.51\%), and Fusarium sp (15.38\%). 


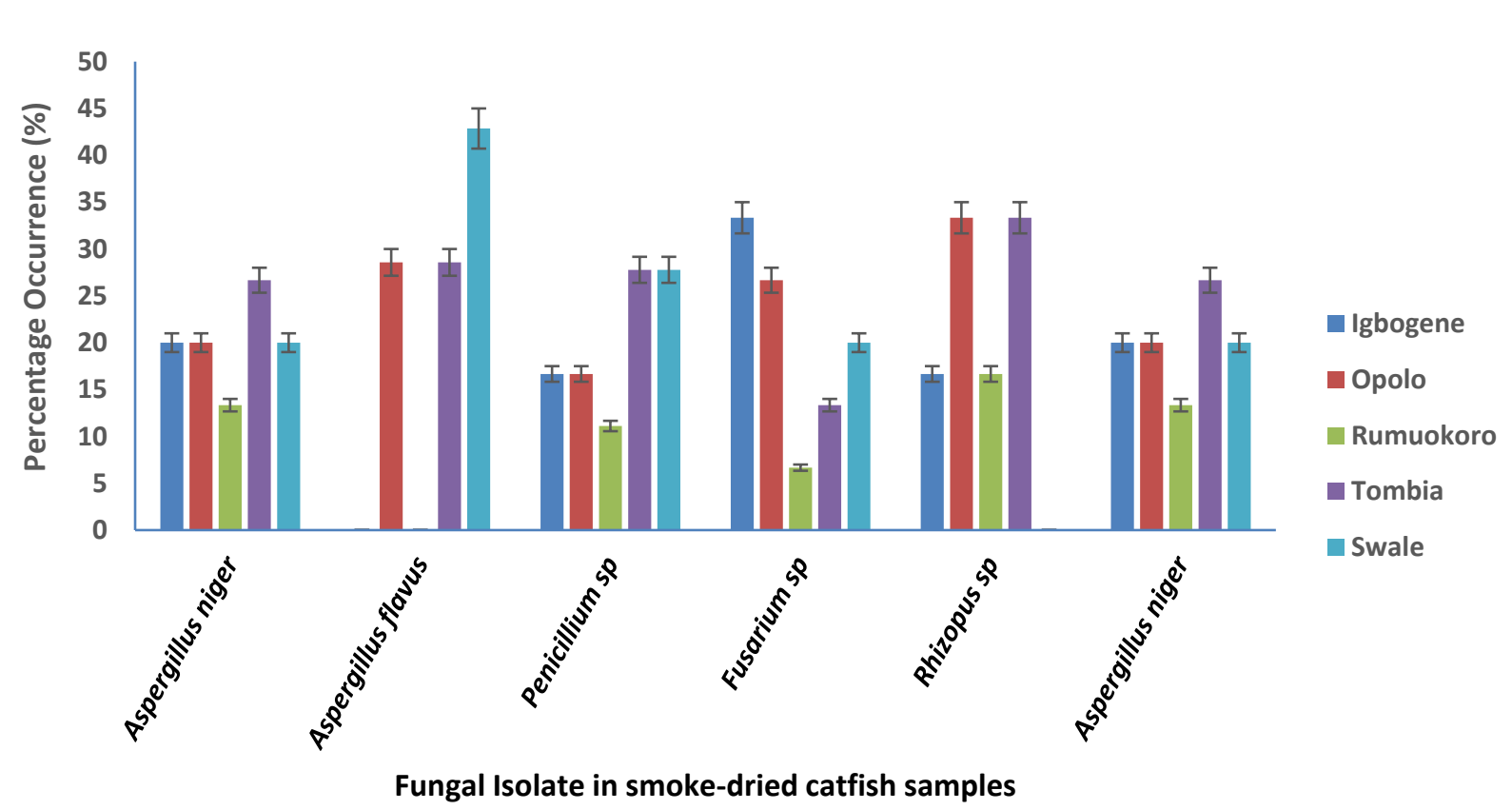

Fig. 3: Frequency of occurrence of fungi isolated from smoke-dried catfish samples

\section{DISCUSSION}

The high microbial loads recorded in this study may be due to handling, packaging and ware display, roasting procedure and/or the moisture content of the fish. The highest bacterial load which was observed in the Igbogene abattoir is average in size compared to other abattoirs. Other factors such as the hygiene of handlers, the degree of contamination at the fish source and how the exposure of the fishes play an important contributory role to microbial load. The lowest microbial load which was recorded in catfishes bought from the Tombia abattoir could be attributed to the minimal fish roasting activities in the region despite the large size of the abattoir. Other fish merchants bring in already roasted fish to sell within the premises.

The organisms obtained in this investigation have been reported in smoked fish by other researchers. The organisms obtained in this investigation have been reported in catfish by other researchers (Adegunloye and Sanusi, 2019; Daramola et al., 2020). This report corroborates the report of Oku and Amakoromo (2013) who reported the presence of Bacillus and Pseudomonas sp. in smoked fish samples obtained from Tombia and Swale markets. The proliferation of bacteria on smoked fish samples might be due to its high moisture (despite drying), and also the increase in temperature that favoured their growth (Ibrahim et al., 2014). More so, Bacillus sp are known to produce endospores especially during adverse conditions and this has been one of the ways they adapt to harsh environmental conditions. Micrococcus species was isolated from both fresh and smoked fish by Ibrahim et al. (2014) which agreed with the result of our findings. This organism is known to be heat resistant and thus may have been able to survive the process of heat treatment on the fish and also survive during storage. Escherichia coli Shigella sp and Salmonella sp., are faecal borne pathogens and they could occur as a result of contamination from the handlers. Their presence in the catfish samples is an indication of recent faecal pollution. Fish harvested from contaminated waters can also 
harbour Salmonella sp. The study of Ibrahim et al. (2014) showed that the following bacteria Staphylococcus aureus, Bacillus subtilis, Staphylococcus epidermis, Salmonella epidermis, Salmonella typhii, Streptococcus spp. and Shigella spp were associated with smoked fish (Clarias gariepinus) which also agreed with the findings of this current study except for Streptococcus sp which was not isolated in this study.

The presence of these organisms calls for caution because they are implicated in fish-borne human diseases (Babu, 2000). Furthermore, fungi isolated from smoked catfish in this study harbour toxigenic genera. Aspergillus species produce aflatoxins which are known to be toxic and carcinogenic. This study report corroborates that of Jimoh et al. (2014) who also isolated the aforementioned fungi from smoked catfish in Ibadan. Adelaja et al., (2013) isolated Staphylococcus sp. Escherichia coli and Aspergillus fumigatus from smoked Chrysichthys nigrodigitatus while Adedeji and Ibrahin (2011) reported similar organisms from fresh shrimps purchased from various markets in Southwestern Nigeria. Job et al., (2016) obtained Fusarium, Aspergillus, Saccharomyces, Penicillium, Mucor, Rhodotorula, Schizosaccharomyces, Acremonium and Rhizopus from smoked fishes in Jos metropolis.

Furthermore, several bacterial and fungal isolates have demonstrated hydrocarbon-using capability. This might be due to the organism being exposed to certain complicated smoke components (which includes but is not limited to PAHs). The search for hydrocarbon utilizing microbes will continue to be novel.

\section{CONCLUSION}

The drive to increase food production due to world population increase and high demand for meat and fish products has led to the need for increased industrial and anthropogenic activities and the consequent release of millions of toxic and recalcitrant chemicals into the environment. The assessment of microbial contaminants on the roasted catfish indicated a very high microbial load of pathogenic bacteria that are of public health importance. Also, fungi that are known for producing aflatoxins were also isolated from the roasted catfish. Aside from the fact that these microorganisms will continue to proliferate and decrease the shelf life of the fish in storage, the fish serves as a point of communing microbial infection to man. This is due largely to the fact that smoked fish are consumed directly along with other products like cassava without any prior cooking or washing (as a snack in the Niger Delta area). These contaminations are due largely to the poor handling by people involved in the vocation, lack of proper sanitary practices, poor and inconsistent roasting conditions, poor packaging, unhygienic display of fish in the markets and lack of proper education.

The abundance of these pathogenic organisms on smoked fish portrays that traditional methods currently employed in the predominant fishing communities of the Niger Delta region for smoking are inadequate. Traditional methods of preserving fish by the fish traders and hawkers must be improved upon in Nigeria at large to reduce post-harvest losses, post-processing contamination, make fish available to consumers, improve the quality of fish products and reduce the health risks associated with consumption microbial contaminated foods. Inasmuch as the consumption of roasted fish with other snacks (without any post-purchase processing) is a common practice in the Niger Delta, the need for improved processing, packaging and handling of smoked fish is imperative. 


\section{REFERENCES}

Aberoumand, A. (2010). Estimation of microbiological variations in minced lean fish products. World Journal of Fish and Marine Science, 2(3): 204 - 207

Adedeji, O.B. and Ibrahim, S.O. (2011). Assessment of Microbial safety of fresh shrimps offered for sale at Alesinloye and Eleyele markets in Ibadan, Southwestern Nigeria. J. App. Sci. in Environmental Sanitation 6(3): 239-346

Adegunloye, D.V.1 and Sanusi A.I. (2019). Microbiota of catfish (Clarias glariepinus) tissues harvested from vials polluted with soil from the e-wastes dumpsite. International Journal of Fisheries and Aquaculture., Vol. 11(5), pp. 104-111

Adelaja, O.A., Olaoye, O.J., Ikenweiwe, N.J. and Ashley-Dejo, S.S. (2013). Comparison of microbial load associated with smoked fish (Chrysichthys nigrodigitatus) from Oyan Lake and Ogun Waterside in Ogun State, Nigeria. Global J. Sci. Frontier Res. Agri. and Vet., 13(8): 34-39.

Adesemoye, A.O., Opere, B.O. and Makinde, S.C.O. (2006). Microbial content of abattoir wastewater and its contaminated soil in Lagos, Nigeria. Afri. J of Biotech. 5(20): 19631968

Akinola, O.A., Akinyemi, A.A. and Bolaji, B.O. (2006). Evaluation of traditional and solar drying systems towards enhancing fish storage and preservation in Nigeria (Abeokuta LocalGovernment as a case study). J. Fish. Int., 1(2-4): 44-49.

Al- Jufaili, M.S. and Opara, L.U (2006). Status of fisheries post-harvest industry in the sultanate of Oman: Part 1 handling and marketing system of fresh fish. J. Fish. Int., 1(24): $144-149 b$.

Babu, P. S. (2000). Ichyozoonoses. Fish farmer International, 14: 14-17

Barnett, H.L., and Hunter, B. (1998). Illustrated genera of imperfecti fungi, 3rd edn. Burges publishing company, USA.

Cheesbrough M. (2004). District laboratory practice in tropical countries. Low price edition part 2. Cambridge Press, England.

Daramola, J. A., Alao, F. O. and Adeniyi, A. E (2020). Estimation of Bacteria and Fungi in Smoked Catfish (Clarias gariepinus) available In Ota Markets. Journal of Research in Forestry, Wildlife and Environment Vol. 12(2) pp 65-73.

Davies, R.M and Davies. O.A, (2009). Traditional and Improved Fish Processing Technologies in Values of Fish. (Tropical Science) 33:183-189.

Douglas, S. I. and Robinson, V. K. (2018). Fungal Pollution of Indoor Air of Some Health Facilities in Rivers State. International Journal of Tropical Disease \& Health; 32(2): 17.

Eyo, A. (2001). Fish Processing Technology in the Tropics. Published by National Institute for Freshwater Fisheries Research (NIFFR), New Bussa, Nigeria. Ezeonu, F.C., Musa, A., Stanly, C.D., Oswald, C.E (2002) Iron and zinc status in soils, water and stable food cultivars in Itakpe, Kogi state of Nigeria. The Environmentalist. 22; 237-240.

Garcia-Falcon MS, Simal-Gandara J (2005). Polycyclic aromatic hydrocarbons in smoke from different woods and their transfer during traditional smoking into chorizo sausages with collagen and tripe casings. Food Addit. Contam., 22: 1-8.

Holt, J.G., N.R. Krieg, P.H.A. Sneath, J.T. Staley and S.T. Williams, 1994. Bergey's Manual of Determinative Bacteriology. 9th Edn., Williams and Wilkins, Baltimore, Maryland, USA.: 1261-1434. 
Ibrahim, B., Baba, J., and Sheshi, M. (2014).Isolation and Identification of Bacteria Associated with Fresh and Smoked Fish (Clarias gariepinus) In Minna Metropolis, Niger State. Nigeria. Journal of Applied \& Environmental Microbiology, 2: 81-85.

Jimoh W.A., Ayeloja, A.A., Oladele-Bukola M.O., Adebayo M.D., Azeez A.F. and Salami S.R. (2014). Isolation of Fungi Infesting Smoked African Catfish from Markets in Ibadan, Nigeria. Nigerian Journal of Fisheries and Aquaculture 2(2): $13-17$.

Job, M. O., Agina, S.E. and Dapiya, H, S. (2016). Occurrence of Aflatoxigenic Fungi in Smoke-dried Fish Sold in Jos Metropolis. British Microbiology Research Journal 11(1): 1-7.

Nigerians Pilot (2015). Nigeria produces 900,000 tonnes of catfish. Oct 2015 Newspaper report.

Odokuma L.O. (2003) The Techniques in Aquatic Microbiology. In: Onyeike, E. N. and osuji, J. O. (eds) Research Techniques in Biological and Chemical Sciences. 1st ed. Springfield Publishers Ltd, Owerri; 156-173

Okerentugba P.O and Ezeronye O.U; (2003). Petroleum degradation potentials of single and mixed microbial cultures isolated from rivers and refinery effluents in Nigeria. Afr. J. Biotechnol. 2(9) $288-292$.

Okonta, A.A. and J.K. Ekelemu, 2005. A preliminary study of micro-organisms associated with fish spoilage in Asaba, Southern Nigeria. Proceedings of the 20th Annual Conference of the Fisheries Society of Nigeria (FISON), Port Harcourt, 14th-18th November, pp: 557-560

Oku, I. and Amakoromo, E. (2013). Microflora of fresh and smoke-dried fish in Yenogoa metropolis, Nigeria. African Journal of Microbiological Research. 7: 4451-4456

Olayemi, F., Raji A., \& Adedayo M. (2012). Microbiological quality of catfish (Clarias gariepinus) smoked with Nigerian Stored Products Research Institute (NSPRI) developed smoking kiln. International Research Journal of Microbiology (IRJM), 3(13), 2141-5463.

Prescott, L. M., Harley, J. P. and Klein, O. A. (2005). Microbiology. 6th edition. Mc-Graw Hills, New York. 